\title{
EXPOSITION
}

\section{Legislation and Research Activity in Belarus about the Radiological Consequences of the Chernobyl Accident: Historical Review and Present Situation}

\author{
Vladimir P. MATSKO ${ }^{* * 1}$ and Tetsuji IMANAKA ${ }^{* * * 2}$
}

(Received December 20, 1996)

KEY WORDS: Chernobyl accident, Belarus, radioactive pollution, research activity, radiation safety regulation

\section{INTRODUCTION}

For nearly ten years since the April 26, 1986 explosion of the Chernobyl power plant nuclear reactor, the Republic of Belarus has subsequently been exposed to conditions of global radioactive contamination. That day ten years ago split the history of Belarus into two epochs-before and after Chernobyl. Judging by its scale, the Chernobyl accident was the biggest technogenious catastrophe that has ever occurred on this planet. Its radioactive cloud virtually covered the whole northern hemisphere, and resulted in the generation of a hitherto unknown mass of refugees, i.e. for ecological reasons, whose numbers only equal those produced by wars.

The most grave results of the accident were to be found in Belarus. Scientists are still arguing as to the exact amount of radionuclides released into the environment by the explosion. However, the most conservative estimate suggests it is equal to the effect of an explosion of twenty nuclear bombs. The damage caused to the Republic by the Cher-

* ウラジーミル・P・マツコ, ** 今中哲二

*1 Institute of Radiobiology, Academy of Sciences of Belarus ; Zhodinskaya St.2, Minsk, 220600 Belarus.

*2 Research Reactor Institute, Kyoto University ; Kumatoricho, Sennan-gun, Osaka 590-04.

京都大学原子炉実験所；大阪府泉南郡熊取町（干 590-04） nobyl accident is estimated to be equal to 32 pre-accidental annual budgets. The scale of the accident demanded urgent countermeasures. During the initial stage of the post-accident period 24,700 people were evacuated. Up to the present, 130,000 people from the contaminated areas have been resettled.

Despite the fact that 10 years have passed since the accident, the problems resulting from it have not disappeared. Moreover, in some realms they have become even worse. This is tied to the high collective dosage of radiation absorbed by the population, to the difficulties in remote impact forecasting (especially against a background of our adverse ecological situation), as well as for other objective reasons.

The Republic, left practically alone to face the catastrophe's consequences, still faces a critical situation today. $1,840,951$ people including 483,869 children below the age of 17 , inhabit 3,221 villages and towns in the radioactively contaminated territories. The radiation dose in some of them is up to $5 \mathrm{mSv}$ or higher per year. Socio-psychological tension is still very high, and there has been a steady increase in the incidence and prevalence of illness. In particular, concern has arisen over the growing number of thyroid pathologies, including thyroid gland cancer among children. 
Aware of the global nature of the catastrophe, and of threatening implications for public health, the Supreme Soviet of Belarus declared the entire territory of the Republic to be a zone of ecological calamity.

\section{LEGISLATION AND REGULATION IN BELARUS CONCERNING CHERNOBYL}

\section{2.a. Legislation to assist people suffering due to the accident}

The Republic of Belarus' "Social Protection of Citizens Affected by the Chernobyl APS Catastrophe" Law proposed on February 22, 1991 was approved on December 11, 1991 with amendments and additions. This law is designed to protect the rights and interests of citizens who took part in the liquidation of the Chernobyl accident, as well as those who were evacuated from the radioactively polluted territories, and those who still live on these territories. This law provides that citizens living or working on the territory of the Republic of Belarus who experienced damage to their health or property due to the Chernobyl APS accident are guaranteed certain rights and compensation by the State.

The basic criterion used to evaluate the areas in which the living and working conditions of the population do not face any restriction is an effective equivalent dose of living population which does not exceed $1 \mathrm{mSv}(0.1 \mathrm{rem})$ per year. According to the stipulations of the Republic of Belarus' "Legal Status of Territories Exposed to Radioactive Pollution as a Result of the Chernobyl APS Catastrophe" Law, following zones are designated on the polluted territory:

-zone of evacuation (alienation);

-zone of first-place resettlement;

-zone of subsequent resettlement;

-zone with the right of resettlement;

-zone having periodic radiation control.

This law guarantees the right of Belarus citizens to obtain complete, timely, and verifiable information about the level of radioactive pollution of the territory, the degree of radionuclide contamination of food products and other consumable commod- ities, and the requirements of the radiation safety regime. This law considers workers who participated in the liquidation of the Chernobyl accident as people affected by the catastrophe. Also covered are citizens of Belarus who took part in the liquidation or were affected by other accidents and their consequences at other nuclear installations, whether civil or military.

It foresees considerable privileges for those who participated in the liquidation of Chernobyl and for those others who were affected by the accident (free receipt of medicines upon physician prescriptions, free annual treatment in sanatoria and health resorts, 50-percent off lodging payments, a 50percent reduction in heating, water, gas, and electricity payments, income tax exemption, increase in annual holidays, etc.). The people affected by the Chernobyl catastrophe have the right to receive pensions before the age proscribed by law. Pensions will also be in full irrespective of the salary received. This law also determines duty of the military to keep watch on the polluted territories.

A Decree of A.G. Lukashenko, President of the Republic of Belarus, on September 1, 1995, attempted to suspend the action of a number of articles of this law relating to the privileges of citizens affected by the Chernobyl catastrophe. However, the Constitutional Court canceled that presidential decree.

\section{2.b. Legislation and regulation pertaining to the radiation dose limit}

After agreeing with Academician L. A. IL'IN, the President of the National Committee on Radiation Protection (NCRP) at the Ministry of Health of the USSR, A.I. KondRUSEv, the Chief State Sanitarian of the USSR, upon the presentation of his deputy A.I. ZAJCHENKO, approved on November 22, 1988, a limit on the individual dose per life for the population of controlled areas of Russia, Belarus and Ukraine which were radioactively polluted as a result of the Chernobyl accident. This is a 1-page document with 6 pages of explication grounding a 35 rem per life limit as the basic concept for "safe living" of population (Letter of NCRP No. 51-2$10 / 4212$ of July 25,1989 ). After this, there began discussion of the concept at the Congress of People's 
Deputies, evaluations of the situation by scientists of the Academy of Sciences of Byelorussian SSR, the Ministry of Education, the Gosagroprom, the Ministry of Health and the Ministry of Social Security of BSSR. After the discussion in the Academy of Sciences of BSSR in July of 1989 with the participation of WHO experts who supported the concepts, the Presidium of the Academy of Sciences of BSSR decided to disagree with the proposed concept of safe living and the opinion of invited foreign scientists. The principal remarks made by the Byelorussian scientists were based on the following deficiencies in the proposed concept (35 rem per life):

- there was no system to control the dose commitment formation, nor any concrete measure to provide safe living and working environment for separate districts, categories of population, etc.; -the data on the "dose-effect" dependence for long-term (70 years) irradiation were not adduced;

-a risk assessment of stochastic effects was not made relating to the present situation;

- radiation effects were not evaluated against a scenario of the joint action of a multitude of irrational factors;

- there was no analysis of data on the irradiation of different population categories in the first period after the accident when people lived without any restrictions and iodine prophylaxy was not carried out (,which undoubtedly will have future repercussions);

- the endemicity of separate territories relating to iodine and related health disturbances were not taken into account;

- the separate accumulation of plutonium, strontium, "hot" particles in the lungs and strontium in bone, etc. was not considered; however, it may become the leading factor in development of pathologies;

-there was no "risk-profit" assessment, etc.

These and other remarks were considered during a session of a number of scientific councils in the Academy of Sciences of the USSR in May of 1989, and on September 15, 1989 during a session of the State Council at the Presidium of the Academy of
Sciences of the USSR. Representatives of the USSR Ministry of Health, NCRP, Academy of Sciences of Ukrainian SSR et al. participated. The most important conclusions arrived at were as follows:

1) Taking into account the generally accepted concept of a non-threshold "dose-effect" dependence, any dose can not be considered as absolutely safe. This means, the concept of safe living on polluted territory requires revision and additional grounding.

2) According to available data, it is impossible to assess correctly the expected risk for the effect of chronic low (from 0 to 100 rem per life) radiation doses.

3) The " 35 rem per life" dose must be considered as the limit, overstepping of which or the risk of overstepping of which is unacceptable. In the case of territories where the people receive less than the 35 rem limit, each case must be decided by means of a complex approach and optimization "input-output" analysis. Moreover, if the safety of the people can not be guaranteed by countermeasures, then resettlement is mandated.

4) The people must be fully informed about the consequences of living on polluted territories, the planned governmental activities, and then have the opportunity to voluntarily decide whether or not to continue living on polluted territories.

As a result of these conclusions, the "Concept of People's Living in Regions Affected by the Chernobyl APS Catastrophe" was developed. It was proposed in this Concept:

1) To define an additionally acceptable irradiation limit not higher than $0.1 \mathrm{rem}(1 \mathrm{mSv})$ per year for the living and working conditions of the population. This irradiation limit can be reached by stages: $1991-0.5 \mathrm{rem}(5 \mathrm{mSv})$ per year, 1993 $-0.3 \mathrm{rem}(3 \mathrm{mSv})$ per year, 1995-0.2 rem (2 $\mathrm{mSv})$ per year, $1998-0.1 \mathrm{rem}(1 \mathrm{mSv})$ per year.

2) To divide all the territories into zones according to the density of radionuclide pollution:

-zone of alienation: zone of resettlement in 1986, adjacent to the Chernobyl APS territory;

-zone of obligatory resettlement: zone with a density of soils polluted with Cesium-137, 
Strontium-90 and plutonium-1480, 111 and 3.7 $\mathrm{kBq} / \mathrm{m}^{2}$, respectively, or higher;

-zone of resettlement: territory with a density of soils polluted with Cesium-137, Strontium-90 and plutonium, respectively, from 555 to 1480 , from 74 to 111 and 1.85 to $3.7 \mathrm{kBq} / \mathrm{m}^{2}$ where the irradiation dose of a person may exceed $0.5 \mathrm{rem}$ (5 mSv) per year;

-zone with the right of resettlement: territory with a density of soils polluted with Cesium-137, Strontium-90 and plutonium, respectively, from 185 to 555 , from 18.5 to 74 and 0.37 to $1.85 \mathrm{kBq} /$ $\mathrm{m}^{2}$, where the acceptable limit of population irradiation is higher than $0.1 \mathrm{rem}(1 \mathrm{mSv})$ per year;

-zone of living under periodical control: territory with a density of soils polluted with Cesium-137 -from 37 to $185 \mathrm{kBq} / \mathrm{m}^{2}$, where the acceptable limit of population irradiation is not higher than $0.1 \mathrm{rem}(1 \mathrm{mSv})$ per year.

The Council of Ministers of Belarus makes decisions on the resettlement and providing for acceptable living conditions. This Concept was approved on December 19, 1990 by the Bureau of the Presidium of the Academy of Sciences of Belarus and became the basis of the abovementioned "Social Protection of Citizens Affected by the Chernobyl APS Catastrophe" Law. The "Legal Status of Territories Exposed to the Radioactive Pollution as a Result of the Chernobyl APS Catastrophe" Law was adopted by the Supreme Soviet on November 12, 1991.

In order to fulfill the protective and other measures indicated by these laws, since 1991, the Ministry of Health has calculated, updated, and filled out the "Catalogue of Doses of Republic of Belarus Populations Living in Settlements with a Level of Cs-137 Pollution Higher Than $37 \mathrm{kBq} /$ $\mathrm{m}^{2}$."

\section{2.c. Legislation and regulation concerning radioactivity levels in foods, water and air}

The basic principles for limitations and prohibitions on agricultural production and consumption of agricultural products, as well as the harvest and storage of forest food products, wildfowl, and fish are laid down in articles 21-25 of the "Legal Status of Territories Exposed to the Radioactive Pollution as a Result of the Chernobyl APS Catastrophe" Law and are differentiated according to the division of polluted territories defined by this law.

On the basis of emergency dose limits (the first year after the catastrophe $-10 \mathrm{rem}, 1987-5 \mathrm{rem}$, 1988-3 rem, 1989-3 rem, 1990-0.5 rem; 50\%external irradiation, 50\%-internal one), the Ministry of Health of the former USSR defined in 1986, 1988, and 1991, the tentative acceptable levels (TAL) of Cesium-137 radionuclide content in food products and potable water. TAL- 88 were adopted, most likely, on the basis of the concept of "safe living" with an absorbed dose limit of 35 rem per life, which was adopted in the same year by the Ministry of Health of the former USSR.

In 1990, the Republic of Belarus "Social Protection of Citizens Affected by the Chernobyl APS Catastrophe" Law was prepared. Since August 1, 1990, the Government of Belarus has put in force the republican control levels (RCL-90) of acceptable radionuclide content in water and food products. The RCL-90 enforced for two years until June of 1992. The RCL-90 rates predicted that for a constant radionuclide intake from food products, the annual dose of internal irradiation of the critical population group would consist of not more than 0.17 rem. The RCL-90 first included the control levels of Strontium-90 in potable water and food products. In the beginning of 1991, the Ministry of Health of the former USSR began to enforce the new TAL of Cesium-137 and Strontium-90 content in potable water and food products. Values of TAL-86, TAL-88, TAL-91 and RCL-90 are shown in Table 1.

At present, the republican acceptable levels (RAL-92) remain in force for cesium and strontium radionuclide content in food products and potable water, which were approved on October 21, 1992 by the Chief State Sanitarian of the Republic of Belarus. RAL-92 assume that radionuclide intake by humans on such a level will comprise an effective equivalent dose not higher than $1 \mathrm{mSv}$ per year (Table 2). 
Table 1 Tentative acceptable levels (TAL) and republican control levels (RCL) of Cesium-137 and Strontium-90 content in food products and potable water, defined in connection with the Chernobyl APS accident

\begin{tabular}{|c|c|c|c|c|}
\hline Name of product & $\begin{array}{l}\mathrm{TAL}-86 \\
\mathrm{~Bq} / \mathrm{kg}, l\end{array}$ & $\begin{array}{l}\text { TAL-88 } \\
\mathrm{Bq} / \mathrm{kg}, l\end{array}$ & $\begin{array}{l}\text { TAL-91 } \\
\mathrm{Bq} / \mathrm{kg}, l\end{array}$ & $\begin{array}{l}\mathrm{RCL}-90 \\
\mathrm{~Bq} / \mathrm{kg}, l\end{array}$ \\
\hline \multicolumn{5}{|l|}{ For Cesium-137 } \\
\hline 1. Potable water & 370 & 18.5 & 18.5 & 18.5 \\
\hline 2. Milk & 370 & 370 & 370 & 185 \\
\hline 3. Lactic products, sour cream, curds & 3700 & 370 & 370 & 185 \\
\hline 4. Milk powder & 18500 & 1850 & 1850 & 740 \\
\hline \multirow[t]{2}{*}{ 5. Butter, condensed milk } & & & 370 & \\
\hline & 7400 & 1100 & 1100 & 370 \\
\hline $\begin{array}{l}\text { 6. Meat (pork, mutton), poultry, fish, eggs, meat and fish } \\
\text { products }\end{array}$ & 3700 & 1850 & 740 & 592 \\
\hline 7. Beef and beef products & 3700 & 2960 & 740 & 592 \\
\hline 8. Vegetable and animal fats, margarine & 7400 & 370 & 185 & 185 \\
\hline 9. Potatoes, verdure & 3700 & 740 & 600 & 592 \\
\hline 10. Vegetables, orchard fruits and berries & 3700 & 740 & 600 & 185 \\
\hline 11. Bread and bread products, grains, oats, flour, sugar & - & 370 & 370 & 370 \\
\hline 12. Canned fruit and vegetables, juices, honey & - & 740 & 600 & 185 \\
\hline 13. Infant food & - & 1850 & 185 & 37 \\
\hline 14. Fresh berries (forest and orchard) & - & - & 1480 & 185 \\
\hline 15. Fresh mushrooms & - & - & 1480 & 370 \\
\hline 16. Dried fruits, mushrooms and forest berries & - & 11100 & 7400 & 3700 \\
\hline 17. Medicinal plants, tea & - & - & 7400 & 1850 \\
\hline 18. Other food products and additives & - & - & - & 592 \\
\hline \multicolumn{5}{|l|}{ For Strontium-90 } \\
\hline 1. Potable water & - & - & 3.7 & 0.37 \\
\hline 2. Milk and milk products & - & - & 37 & 3.7 \\
\hline 3. Milk powder & - & - & 185 & 18.5 \\
\hline 4. Condensed milk & - & - & 111 & 3.7 \\
\hline 5. Concentrated milk, butter & - & - & - & 3.7 \\
\hline $\begin{array}{l}\text { 6. Meat (beef, pork, mutton), poultry, fish, eggs, meat and } \\
\text { fish products, vegetable and animal fats, margarine }\end{array}$ & - & - & - & 18.5 \\
\hline 7. Potatoes & - & - & 37 & - \\
\hline 8. All types of infant food (ready to be consumed) & - & - & 3.7 & 1.85 \\
\hline 9. Bread and bread products, grains, oats, flour, sugar & - & - & 37 & 3.7 \\
\hline
\end{tabular}

\section{ACTIVITY OF GOVERNMENTAL ORGANIZATION CONCERNING CHERNOBYL}

\section{3.a. Basic governmental policy}

The activity of the Belarus Government concerning the mitigation of the Chernobyl catastrophe may be divided conditionally into two periods (before and after the collapse of the USSR) and 5 stages. In the first period, the government of the Republic, recuperating after the shock, made policy determined principally by the Central Committee of the CPSU (Communist Party of the Soviet Union) and the USSR Government. After the collapse of the USSR, when the hope to obtain help from other republics of the former USSR 
Table 2 Fixed values (RAL-92)

a) for Cesium-137

\begin{tabular}{lc}
\hline Name of food product & $\mathrm{Bq} / \mathrm{kg}, l$ \\
\hline 1. Potable water & 18.5 \\
2. Milk and milk products & 111 \\
3. Milk powder & 740 \\
4. Meat and meat products & 600 \\
5. Potatoes and root vegetables & 370 \\
6. Bread and bread products & 185 \\
7. Flour, grains, oats, sugar, honey & 370 \\
8. Vegetable and animal fats, margarine & 185 \\
9. Vegetables, orchard fruits and berries, & 185 \\
forest berries & 185 \\
10. Canned vegetables, orchard fruits and & \\
berries & 3700 \\
11. Dried mushrooms & 37 \\
12. All types of infant food (ready to be & \\
consumed) & 370 \\
13. Other food products (ready to be con- \\
sumed)
\end{tabular}

b) for Strontium-90

\begin{tabular}{lc}
\hline Name of food product & $\mathrm{Bq} / \mathrm{kg}, l$ \\
\hline 1. Potable water & 0.37 \\
2. Milk and milk products & 3.7 \\
3. Bread and bread products & 3.7 \\
4. Potatoes & 3.7 \\
5. All types of infant food (ready to be & 1.85 \\
\hline & \\
\hline
\end{tabular}

(predominantly Russia) was lost, the Belarus Government began to make independent policy concerning Chernobyl.

During the first stage (April-May 1986), the socio-economic conditions in the Republic favored pursuing various directions in spite of their inconsistencies. The greatest error of that period was that the population was not informed about the danger of radiation. The opinion that panic would arise was not grounded. Due to the secrecy surrounding the scale of the disaster, only about 170,000 people received iodine prophylaxy instead of the entire populations of four regions: Mogilev, Gomel, Brest and Minsk. Regarding the objective difficulties of solving the primary prophylaxy and deconta- mination tasks, the insufficiency of portable equipment, medications, and portable sanitation installations should be taken into account.

In the second stage (June-December 1986), more than 25 different decrees and instructions were promulgated by the Council of Ministers of the Byelorussian SSR and the Central Committee of the CPB (Communist Party of Belarus). Incidentally, their principal activity was directed to the financial support of affected citizens, as well as to the privileges and donations to population living in areas with a pollution density higher than 1,480 $\mathrm{kBq} / \mathrm{m}^{2}$. Those acts were conditioned mainly by the massive departure of population from the most polluted areas of the Gomel region and, a little later, the Mogilev region. At the same time, there were not clear enough recommendations regarding the production of "clean" agricultural products. Practically all the yield of 1986 was processed to be consumed, except for the yield from the $30-\mathrm{km}$ zone. In this stage, a negative practice was begun to restrain the population from leaving the area by offering financial incentives, even though the resettlement of people from especially affected areas was needed.

The third stage (1987-1988) is characterized by socio-economic and political instability. Unnecessary products were produced in polluted areas. The number of cases of diseases caused by small radiation doses increased. Meetings and demonstrations began to occur, which were the result of contradictions in the development of concept of safe living between the central government and Republican's scientific and economic bodies. The Republic still supplied animal and plant products to the USSR fund in full-volume. Activity was mainly directed towards decontamination and agrotechnical works on lowering the radioactive pollution levels. In polluted settlements with a level of pollution higher than $555 \mathrm{kBq} / \mathrm{m}^{2}$, pipelines for gas heating, schools, and polyclinics were built. Later, those territories were transformed to a regime of strong control, and all social and economic activities were halted.

In the fourth stage (1989), it became obvious that it was impossible to solve all of the complex 
problems related to the consequences of the accident without adopting a clear overall program. Such a program was developed and adopted, but it was late in many respects. Adequate material resources were not provided to carry out the program tasks. The 5-year program implementation plan became strategically obsolete. The fact that solving the problems of the population would take five years did not gain the approval of the people.

The fifth stage (1990-) is characterized by a dramatic shift from instructions and decrees to the elaboration of legislative acts: the "Social Protection of Citizens Affected by the Chernobyl APS Catastrophe" Law and "Legal Status of Territories Exposed to the Radioactive Pollution as a result of the Chernobyl APS Catastrophe" Law were elaborated and adopted. The State Committee on the Problems of the Chernobyl APS Accident was created at the Council of Ministers of the BSSR. Governmental activities included all aspects of the liquidation of the accident's consequences and were oriented towards:

- the resettlement of inhabitants of the most polluted regions;

-the provision of medical assistance to sufferers;

-the construction of new dwellings and opening of new jobs for the migrants;

-the creation of radiation control system;

- the isolation of the most polluted areas;

-the sanitarian-ecological planning of settlements in polluted zones;

- the organization of scientific investigations of the consequences of the accident, etc.

\section{3.b. Ministry activity concerning Chernobyl}

Primarily, all the decisions concerning Chernobyl were made in Belarus by the Commission on the Liquidation of the Consequences of the Chernobyl APS Accident at the Bureau of the Central Committee of the CPB and the Council of Ministers of the BSSR.

According to a decision by the Supreme Soviet in 1991, the State Committee on the Problems of the Chernobyl APS Accident was formed. The President of the Committee had a position equal to the Vice-President of the Council of Ministers. In 1994, the State Committee on the Problems of the
Chernobyl APS Accident became the Ministry on Emergencies and Protection of the Population from the Consequences of the Chernobyl APS Catastrophe.

The realization of state policy in protecting the population, in addition to coordinating and controlling the activities of ministries and other central bodies in this direction are the principal tasks of the Ministry in terms of mitigating the consequences of the Chernobyl APS accident. There are subdivisions within the Ministry which control the direction of certain activities toward mitigating the consequences of the catastrophe and in making decisions to be implemented by various branch ministries and institutions, as well as local administrations. For example, the Department of Science and International Relations of the Ministry controls the scale, the nature, and the development of research in the field of Chernobyl-related problems conducted by the Academy of Sciences, universities, and institutes of branch ministries. The Ministry orders and finances these research projects.

\section{3.c. Parliament}

In October of 1989, the Supreme Soviet of the Republic of Belarus adopted the "State Program Mitigating the Consequences of the Chernobyl APS Catastrophe for 1990-1995". Since its adoption, all activity concerning protecting the people from radiation factors, production of "clean" food products, decontamination, and agrochemical works has become more complex and systematic. The tasks foreseen in the Republic's program were partially induced in the "State Union-Republican Program of Emergent Measures on Liquidation of After-Effects of the Chernobyl APS Accident for 1990-1992" which was adopted by the USSR Supreme Soviet. It was expected that, after the implementation of this program, the unionrepublican long-term program on mitigating the consequences of the Chernobyl APS accident for 1993-1995 and until 2000 would be formulated. However, due to the collapse of the Soviet Union, it was not adopted.

In 1990, a session of the Belarus Supreme Soviet defined the Chernobyl problem as a national, 
nodal, which causes political, social, demographic, and economic tension in the Republic, and thereby declared Belarus a zone of ecological disaster. Making up for lost time, the parliament adopted a number of important acts in the short-term. In February of 1991, the "Social Protection of Citizens Affected by the Chernobyl APS Catastrophe" Law was adopted, as well as instructions for a "Complex Special Program of Prophylaxy of Genetic Consequences Influenced by the Chernobyl APS Catastrophe", and a "Complex Special Program of BSSR 'Defense of Maternity and Childhood in the Conditions of Influence of Consequences of the Chernobyl APS Catastrophe' for 1991-1995". The "Legal Status of Territories Exposed to the Radioactive Pollution as a Result of the Chernobyl APS Catastrophe" Law was adopted in November of 1991.

The Permanent Commission of the Supreme Soviet on the Problems of the Chernobyl APS Catastrophe also controls the activity of executive bodies and local administrations on the mitigation of the accident consequences.

\section{ACADEMY OF SCIENCES}

After the Chernobyl APS accident, a number of complicated problems arose in the fields of ecology, medicine, agriculture, law, demography, etc. All the Republic's specialists with corresponding profiles were engaged in the solution of them. In the first stage of the liquidating the accident consequences, work was carried out under the direction of a working group of the Council of Ministers headed by A.A. Petrov. After determining the scale of the disaster, a Governmental Commission was formed, headed by V.G. EvTuKH, the First Vice-President of the Council of Ministers of the Republic. The Science-Technical Council was created for the scientific provision of works as well as the Operative Group-at the Presidium of the Academy of Sciences.

An assessment of the radiation situation and an elaboration of urgent measures to lower the negative effects of radiation on human beings were the principal tasks during the first stage after the accident. Scientists and specialists from the Academy of Sciences, the Ministry of Health, the Ministry of Higher Education, Gosagroprom and other Belarus institutions took part in solving these questions. The research results enabled an assessment of the general characteristics of the radiation situation in the accident zone and adjacent areas and facilitated the creation of maps of radionuclide pollution in the Republic. The data obtained by scientists and specialists from different institutions became the basis for making decisions on additional resettlement of inhabitants of contaminated districts, construction of new dwellings, and norms of radiation safety for industrial activity in polluted zones.

However, it was obvious that in addition to the urgent first-priority activities, the adoption of longterm scientifically grounded measures were also needed in order to fully liquidate the consequences of the accident. It was impossible to elaborate clear recommendations for solutions to these problems based on past international experience of liquidating the consequences of nuclear accidents. Therefore, in July of 1986, according to a proposal made by directive bodies and scientists of Belarus, a complex program of investigations into the problems of liquidating the consequences of the Chernobyl catastrophe was jointly developed in cooperation with Ukraine and Moldova and approved for 1986-1990. This program induced research and experimental and technological works in four principal directions:

- study of radioactive pollution of ecological systems; genetic, physiological, and biochemical assessment of its possible consequences;

- development of technology and methods of agricultural production in the case of pollution of the environment with radionuclides;

- study of the effects of radiation on functional systems of organisms, occurrence and course of human diseases, the development of methods of diagnosis and treatment of radiation injuries;

- development of technologies to decrease radiation pollution of the environment and other separate objects, methods and means of radiometric and dosimetric control.

Specialized scientific institutes and structural subdivisions were created in a number of the 
Republic's ministries and institutions for the implementation of this program, and corresponding tasks were assigned to them. First of all, created were the Institute of Radiobiology of the Academy of Sciences of Belarus (Minsk), the Research Institute of Radiation Medicine (Minsk), Vitebsk, Gomel and Mogilev filial branches of the Research Institute of Radiation Medicine, the Belarus Research Institute of Agricultural Radiology (Gomel). Practically all of the scientific institutions and centers of higher education possessing corresponding specialists and equipment participated in solving the problems which arose. In particular, involved were the Institute of Nuclear Energy of the Academy of Sciences (the Institute of Radioecological Problems later originated from this institute), the Belarus State University, the Belarus Research Institute of Soil Science and Agrochemistry, the Belarus Research Institute of Haematology and Blood Transfusion, the Institute of Oncology and Medical Radiology, and many others. The majority of scientific groups addressed these problems without receiving salaries.

The coordination of efforts by scientific institutions within the program facilitated the fulfillment of operative tasks in the systematically planned studies of accident consequences, with the goal to elaborate measures for their liquidation. Coordination was provided by the Inter-republican Scientific Board consisting of Belarus, Ukrainian and Moldavian sections. The academician E. F. Konoplya became the Co-chairman of the Interrepublican Board and the Chairman of the Belarus section. The program tasks were fulfilled by 18 institutes of the Academy of Sciences and more than 20 scientific and educational centers of the Ministry of Health, Gosagroprom, the Ministry of Higher Education and other organizations in the Republic.

In Belarus, every year plans for research within the program were designed and then approved by the Academy of Sciences and the Commission of Council of Ministers of the Republic. The course and results of the research were discussed in special republican and international seminars, sessions and conferences, and the conclusions and pro- posals made by scientists were submitted to the Government. Simultaneously, the program of monitoring and forecasting the radiation situation in the Republic was created and approved.

As a result of implementing research projects within these programs, a complex assessment of the radioecological situation in the Republic was made. The forms of radionuclides present in different ecosystems were determined, as well as their basic ways of migration. The first results were obtained in the study of the effect of the present situation on functional systems of organisms and the rate of disease in the population. A number of prophylactic medical activities took place; a number of recommendations about agricultural production on polluted territories and the rational use of nature was elaborated; methods of decontamination and cleaning radionuclides from environmental objects were proposed; a forecast of radioactive pollution dynamics in the Belarus territory for the coming years was made.

The results obtained became the basis for a number of protective measures taken by directive bodies, including: the resettlement of inhabitants of the most polluted areas, the selection of places for construction of new settlements, the confirmation of stricter norms on radionuclide content in food products and potable water, the prohibition or limitation of various kinds of economic activity on affected territories.

The significant negative consequences of the accident on a large territory of the Republic which were revealed in 1986-1989, became the reason for elaborating a state program of liquidation of accident consequences for 1990-1995. This program was approved by the XII Session of the Supreme Soviet of Belarus on October 26, 1989. In the state program there is a special section which addresses the scientific provision of works, which is headed by the Institute of Radiobiology of the Academy of Sciences of Belarus. The Coordinative Council was formed in order to coordinate the research and was approved on December 13, 1989 by the Commission on the Questions of Science-Technical Progress of the Council of Ministers of Belarus. Research within the state program is carried out 
based upon a complex arrangement of assignments in the following areas:

- medical consequences of the Chernobyl accident and prognosis of the state of population's health, elaboration of methods of diagnosis, treatment and prophylaxy of diseases of different categories of sufferers (head organization: the Research Institute of Radiation Medicine of the Ministry of Health of Belarus);

- carrying out of agricultural production on contaminated territories, forecasting and working out of protective measures (head organization: the Belarus Research Institute of Soil Science and Agrochemistry of the Ministry of Agriculture and Food of Belarus);

- regularities of changes in the radioecological situation and the effects on the life of organisms in various ecosystems, long-term prognosis of the radioecological situation in the Republic (head organization: the Institute of Radiobiology of the Academy of Sciences of Belarus);

- decontamination, processing, disposal and storage of radioactive wastes and products of decontamination (head organization: the Institute of Radioecological Problems of the Academy of Sciences of Belarus);

- social and economic development of territories affected by the Chernobyl APS catastrophe (head organization: the Institute of Economy of the Academy of Sciences of Belarus);

- problems of social adaptation and social and psychological support of population (head organization: the Institute of Philosophy and Law of the Academy of Sciences of Belarus);

-research and testing of new preparations, compounds and food additives, development of recipes and technologies to produce them (head organization: the Belarus Sanitarian-Hygienical Institute of the Ministry of Health of Belarus);

- design and production of equipment to provide radiometric and dosimetric control (head organization: Belarus State University);

-effects of small irradiation doses (head organization: the Institute of Radiobiology of the Academy of Sciences of Belarus);

- combined effect of ionizing radiation and other injuring factors (head organization: the Research Institute of Radiation Medicine of the Ministry of Health of Belarus);

- rehabilitation of polluted territories (head organization: the Belarus Research Institute of Agricultural Radiology of the Ministry of Agriculture and Food of Belarus);

- provision of information-analysis of scientific issues of the state program (head organization: the Institute of Radiobiology of the Academy of Sciences of Belarus).

The specialized national program approved by the Supreme Soviet of the Republic of Belarus are elements of the state program on liquidation of the consequences of the Chernobyl APS accident. They are as follows:

- prophylaxy of genetic consequences conditioned by the Chernobyl accident (head organization: the Research Institute of Hereditary and Congenital Diseases of the Ministry of Health of Belarus);

- defense of maternity and childhood in areas suffering from the Chernobyl APS accident (head organization: the Belarus Research Institute of Defense of Maternity and Childhood of the Ministry of Health of Belarus).

With the goal to create a radiometric and dosimetric basis in the Republic, instead of issuing a scientific program aimed at creating an equipment basis, the government of Republic adopted an independent republican scientific-technical program on design and production of equipment to provide radiometric and dosimetric control on December 21, 1990.

There are councils of experts within every head organization, who evaluate the projects submitted for inclusion into the state program, provide the expertise for them, draw up annual plans and reports on corresponding branches, and submit them to the Coordinative Council. The Coordinative Council considers the plans and reports of these head organizations, and with the participation of independent experts, prepares reports compiled within the program plans and submits them for confirmation to the Department of Science of the Ministry on Emergencies and Protection of 
Population from the Consequences of the Chernobyl APS Catastrophe.

The research implemented within the state program allows for an objective assessment of the ecological, medical, economic and social consequences of the accident, in order to propose a number of measures oriented to their mitigation. The financial support of such research significantly enhanced their efficiency. The structure and assignment of scientific matters in the state program are constantly being improved according to the demands of addressing practical tasks.

\section{$V$ LIST OF SCIENTIFIC ORGANIZATION WORKING ON CHERNOBYL}

\section{5.a. Physical processes and radioactivity released during the accident}

- sequences and causes of the accident:

The study of the course and causes of the catastrophe falls within the scope of the Institute of Nuclear Energy (currently, the Institute of Problems of Energy of the Academy of Sciences of Belarus) and the scientific center "Belrad."

- behavior of radioactivity release into the atmosphere:

The Institute of Radiobiology (V.P. MIRonov, $\mathrm{Ph}$. D.) and the Center of Radiation Control and Environmental Monitoring of the Committee on Hydrometeorology of Republic of Belarus study the distribution of radioactivity released into the atmosphere during the accident.

- dispersion and deposition of radioactivity in the atmosphere:

The dispersion and migration of radioactivity in the atmosphere and its deposition onto the ground are the subject of studies by the Institute of Radiobiology (V.P. Mironov, Ph. D.), Belarus State University (Professor E.P. Petryaev), and the above-mentioned Center of Radiation Control by which the monitoring of atmosphere pollution is being conducted.

\section{5.b. Radioactivity contamination and moni- toring}

- contamination data in the early stage after the accident:

The data on exposure doses during the early stage after the accident are kept in the Center of Radiation Control and Environmental Monitoring and in the State Committee on Civil Defense.

The data on soil pollution are kept in the Center of Radiation Control as the Republic's data bank on the cesium, strontium and plutonium radionuclide content in soils throughout Belarus during post-Chernobyl years. The Institute of Soil Science and Agrochemistry and the Institute of Radiobiology are also occupied with this question.

The data on food pollution are gathered at the Ministry of Agriculture and Food, the center "Belrad," and sanitation stations in settlements.

- recent contamination data:

The Center of Radiation Control and Environmental Monitoring of the Committee on Hydrometeorology of Republic of Belarus is the center where recent contamination data are kept.

\section{5.c. Dose estimation}

The reconstruction of thyroid dose is the subject of research by V.F. Minenko, Ph. D. (Head of the Laboratory of Radiation Situation Assessment and Dosimetry at the Research Institute of Radiation Medicine). The research is headed by Ya. Eh. Kenigsberg, D. M., Deputy Director of the Institute of Radiation Medicine. They are also involved in the reconstruction of external and internal doses at the early stage after the accident, as well as the prediction of radiation doses. The forecast of the dynamics of doses and radiation risk also fall within the scope of studies by the Laboratory of Radiation Monitoring at the Institute of Radiobiology (Head-V.A. KnatKo, Ph. D.). The rise of thyroid cancer in children dependent on the absorbed dose is the theme of a study by the group handling thyroid morphology research at the Central Research Laboratory of Minsk Medical Institute (Head-Professor E.D. Cherstvou), as well as by the group on tumorous thyroid pathology (Head-Professor E.P. DEMIDCHIK).

\section{5.d. Medical care for people suffering from the accident}

The Ministry of Health of the Republic of Belarus and, more exactly, the Department of Medical Protection from the Consequences of the Chernobyl APS Catastrophe and Emergencies (Head- 
V.A. StezhKo) directs the medical care for the people suffering from the accident. The Department of Radiation Hygiene (Head-V.V. GRIN) and the Section of Radiation Safety Control on the Economical Objects (Head-A.F. KARDASH) are also involved. Immediate medical care is provided by district, town, and regional health departments, in addition to hospitals, polyclinics, and other institutions. The clinic and dispensary of radiation medicine of the Ministry of Health of Belarus is the head medical base.

\section{5.e. Epidemiological study}

The program of registering liquidators, evacuees, and inhabitants of contaminated areas is conducted by the Belarus State Register of citizens subjected to radiation action as a result of the Chernobyl APS catastrophe (a Decree by the Council of Ministers No. 283 of 5/5/1993 determined its status and functions). The Belarus Center of Medical Technologies (Director Professor A.E. OKEANov) is the responsible executive. The Laboratory of Analysis and Control of Data (Head-S.I. ANTIPOVA) is occupied directly with these questions (medicine). Software is provided by the Department of Population Registers Automation (Head-S.M. PolyaKov). In addition, the state of health of the population subjected to radiation action is studied by the Laboratory of Epidemiology of Radiation Actions (Head-K.V. MoshCHIK) at the Research Institute of Radiation Medicine and the Laboratory of Epidemiology and Forecast of the Population's Health of the Belarus Center of Medical Technologies.

\section{SHORT DESCRIPTION OF THE LEAD ORGANIZATIONS}

\section{-Institute of Radiobiology, Academy of Sciences of Belarus}

a. History and aims of the foundation

The Institute was organized in 1987 upon a decree by the Government to be a head organization in the Republic in solving problems caused by Chernobyl.

b. Structure and number of staff in the organization

10 laboratories, 2 departments, 1 group. 85 scien- tists.

c. Research activities relating to Chernobyl

Principal scientific activities:

- study of radionuclide behavior in environmental components: soil, water, air, and plants;

- study of the effects of ionizing radiation on the most important organism's systems: endocrine, immune, cardiovascular, sex, etc.;

- forecast of the dynamics of the radioecological situation and doses of external irradiation; -study of the effects of small irradiation doses; - research for compounds of natural or artificial origin with radioprotective properties.

-Research Institute of Radiation Medicine, Ministry of Health

a. The Institute was organized in 1987 upon a decree by the Government in order to study the medical consequences of the Chernobyl APS catastrophe and to search for ways to mitigate them.

b. 14 laboratories. 89 scientists. 3 affiliated branches in Gomel, Mogilev and Vitebsk.

c. Principal scientific activities:

- dosimetry, doses prognosis, determination of ration components contributing to the formation of internal doses;

-endocrinologic investigations, primarily, thyroid pathology;

-immunological, cytogenetical, epidemiological investigations;

- study of combined effect of radiation and non-radiation factors;

-study of efficiency of sanitation and treatment in sanatoria and resorts.

-Belarus Center of Medical Technologies, Information, Control and Economy of Public Health

a. The Center was organized in 1992 upon a decree by the Government in order to analyze the state of health of the population, to forecast the further development of a public health system, to create data banks and registers of the health state of the population, especially of those affected by the Chernobyl APS accident and those involved with the liquidation.

b. 2 laboratories (15 scientists) are occupied with 
Chernobyl problems.

c. Principal scientific activities:

-epidemiology of malignant neoplasm in the Republic before and after the accident; - study of the health state of different categories of sufferers based on the State Register of citizens subjected to the effects of radiation as a result of the Chernobyl accident, including liquidators, evacuees, inhabitants of polluted areas, as well as their children.

-Institute of Radioecological Problems, Academy of Sciences of Belarus

a. The Institute was organized in 1991, based on part of the former Institute of Nuclear Energy of the Academy of Sciences of Belarus in order to solve problems connected with decontamination, utilization, and burying of radioactive wastes.

b. 8 laboratories. 48 scientists.

c. Principal scientific activities:

- elaboration of methods and means of decontamination and protection of the environment from pollution with decontamination products and buried radioactive wastes;

- elaboration of methods to protect the population from radiation and protective countermeasures, and an evaluation of their efficiency.

- Research Institute of Hereditary and Congenital Diseases, Ministry of Health

a. The Institute was organized in 1988 based on affiliated branch of the Institute of Medical Genetics of the Academy of Medical Sciences of the USSR, in order to elaborate methods of prophylaxy and diagnosis of hereditary and congenital diseases.

b. 2 laboratories, 1 department and 2 groups (total: 20 scientists) are engaged in solving Chernobyl problems.

c. Principal scientific activities:

- biological indication of radiation injury to human hereditary structures;

-monitoring of human hereditary pathology, medico-genetic consultation;

- prenatal diagnosis and prophylaxy of hereditary and congenital diseases of fetus.
-Institute of Genetics and Cytology, Academy of Sciences of Belarus

a. The Institute was organized in 1965 to develop genetic studies of vegetable, microbial, and animal objects in Belarus. After the Chernobyl catastrophe, it was partially re-oriented to study the effect of radioactive contamination of the environment on genetic structures.

b. 2 laboratories, 3 groups, 1 department (total: 34 scientists) are engaged in solving Chernobyl problems.

c. Principal scientific activities:

- study of mutations on the molecular level by feeding experimental animals with contaminated feeds;

- analysis and prognosis of genetic after-effects of the Chernobyl catastrophe on animals and man;

- genetic observation of children living in contaminated areas;

- study of genetically determined rise of tumors in people living in polluted areas;

- elaboration of radioprotective preparations and sensitive methods of bioindication of environmental pollution.

\section{- Research Institute of Haematology and Blood Transfusion, Ministry of Health}

a. The Institute was organized in 1932 as the head republican science-medical organization addressing problems of haematology and blood service. In 1986, the Institute was partially re-oriented to Chernobyl problems.

b. 5 laboratories ( 25 scientists) are engaged in the solution of problems related to Chernobyl.

c. Principal scientific activities:

- analysis of the reaction of haematopoietic and immunocompetent cells to the action of ionizing radiation, primarily, in people affected by the Chernobyl APS catastrophe;

- study of phenotypical and functional disturbances of immunocompetent cells in liquidators; -study of the incidence of haematological diseases in Belarus relating to the Chernobyl accident;

-study of clinical characteristics of leukoses, anemia, and haemostasiopathies in adult 
patients, and the definition of peculiarities in clinical treatment of diseases arising as a result of small irradiation doses.

\section{LIST OF PRINCIPAL SCIENTIFIC CONFERENCE HELD ON CHERNOBYL IN BELARUS}

1. Republican Science-Practical Conference on Radiobiology and Radioecology, December 2223, 1988, Minsk.

2. 1st Science-Practical Conference, December 26-27, 1989, Minsk.

3. Republican Science-Practical Conference on Radiobiology and Radioecology, December 2021, 1990, Minsk.

4. 2nd Science-Practical Conference "SciencePractical Aspects of Preservation of Health of People Exposed to Radiation Action as a Result of Chernobyl APS Catastrophe", March 12-14, 1991, Minsk.

5. Belarus Republican Science-Practical Conference "Psychological Consequences of Chernobyl APS Accident", June 26, 1991, Minsk.

6. International Symposium (with the participation of an international working group on Chernobyl problems) "Man, Ecology, Symmetry", October 9-11, 1991, Minsk.

7. All-Union Conference "Radiobiological Consequences of the Chernobyl APS Accident," October 30-November 1, 1991, Minsk.

8. 3rd Science-Practical Conference, April 1517, 1992, Gomel.

9. International Practical Seminar "Agrotechnical Methods of Improvement on Soils Polluted with Radionuclides," September 1992, Minsk.

10. International Symposium "Effect of Radiation on Thyroid," October 27-30, 1992, Minsk.

11. Belarus Republican Science-Production Conference "Principal Directions of Obtaining Ecologically Clean Plant Production," 1992, Gorki.

12. Science-Practical Conference on Problems of Social and Psychological Rehabilitation and Social-Legal Protection of Children and Adolescents Affected by the Chernobyl APS Accident, April 23-24, 1992, Gomel.
13. 2nd Belarus-German Symposium on Problems of Infant Oncohaematology, April 24-27, 1992, Minsk.

14. International Symposium "Consequences of Nuclear Catastrophes: Chernobyl, Hiroshima, Nagasaki," June 29-July 1, 1992, Minsk.

15. Science-Practical Conference on Problems of Safe Living in the Zone, Wastes Management, Ecological Control, 1992, Gomel.

16. Belarus Republican Science-Practical Conference "Natural and Economical Complexes of Belarus Palesse in Extreme Conditions," May 14-15, 1992, Gomel.

17. Belarus Republican Science-Practical Conference "Psychological Consequences of the Chernobyl APS Accident," June 26, 1992, Minsk.

18. International Symposium "Chernobyl and Health of Children," June 1-5, 1992, Mogilev.

19. International Conference "Science and Medicine for Chernobyl," November 10-13, 1993, Minsk.

20. Conference "Defense of Maternity and Childhood in Conditions of the Chernobyl APS Catastrophe Consequences," January 10-12, 1994, Minsk.

21. 4th Science-Practical Conference "SciencePractical Aspects of Preservation of Health of People Exposed to Radiation Action as a Result of the Chernobyl APS Accident," April 11-13, 1994, Mogilev.

22. 2nd International Congress "World after Chernobyl," April 18-22, 1994, Minsk.

23. Republican Seminar "State and Perspectives of Development of Medico-Genetic Service in Post-Chernobyl Period," June 7-8, 1994, Minsk.

24. Belarus-Japan Symposium "Acute and Late Consequences of Nuclear Catastrophes: Hiroshima-Nagasaki and Chernobyl," October 3-5, 1994, Minsk.

25. International Task-Force Meeting "Ecological Status of Territories Polluted with Radionuclides," April 19-20, 1995, Minsk.

26. Science Conference "Ten Years after the Chernobyl Catastrophe (Scientific Aspects of Problem)," February 28-29, 1996, Minsk.

27. 1st International Conference "Radiological 
Consequences of Chernobyl Catastrophe," March 18-22, 1996, Minsk.

\section{LIST OF IMPORTANT PUBLICATION BY BELARUSSIAN SCIENTISTS ON CHERNOBYL}

1. Avramenko T.A., Drozdovich V.V., Minenko V.F., Tretiakevich S.S., "Radiation, Dose Catalogue of Inhabitants in Settlements on the Republic of Belarus," Minsk, 1992 (in Russian).

2. Astakhova L.N., Polyanskaya O.N., DROzD V.M. et al., "Functional State of Pituitary-Thyroid System in Children and Adolescents," Zdravookhranenie Belarusi. 1993, No. 2, pp. 4-7 (in Russian).

3. Beskorovajnyj V.P., Kotovich V.V., MolodyKh V.G. et al., "Radioactive Pollution on the Belarus Territory by Collapse of the Building Structure of the 4th Block of APS," Vestsi ANB. Seryya fizika-tehkhnichnykh navuk. 1995, No. 1. pp. 93-97 (in Russian).

4. Bondar Yu. I., Shmanaj G.S., Matsko V.P. et al., "Radioactive Pollution on the Territory of the Polesski State Radioecological Reserve," Vestsi AN BSSR. Seryya fizika-ehnergetychnykh navuk. 1991, No. 4, pp. 58-64 (in Russian).

5. Buglova E.E., "Formation of Internal Radiation Dose Dependent on Peculiarities of Cesium Radionuclide Transfer along Food Chain and Efficiency of Protective Measures," Abstracts of Intern. Conf. "Science and Medicine For Chernobyl." Minsk, 10-13 Nov. 1993, pp. 3-4 (in Russian).

6. Eliseeva K.G., Trusova V.D., Vojtovich A.M., SoKolik G.A., "Role of Proliferation Activity of Cells and Level of Radionuclide Accumulation in Injury of Genetic Structure of Animals from the Pollution Zone around Chernobyl APS," Doklady ANSB. 1994, Vol. 38, No. 4, pp. 80-83 (in Russian).

7. ILIN V.P., GUDAK S.P., "Characterization of Radionuclide Migration in the Aeration Zone of South-East of BSSR," Vodnye resursy. 1990, No. 6, pp. 56-60 (in Russian).

8. Kagan L.M., KadatskiJ V.B., "Gamma-
Field Transformation on the Belarus Territory and Assessment of External Radiation Dose as a Result of the Chernobyl APS Accident," Atomnaya ehnergiya. 1994, Vol. 77 , No. 3, pp. 211214 (in Russian).

9. Kenigsberg Ya. Eh., Minenko V.F., Buglova E.E., "Collective Dose of Belarus Population after the Chernobyl APS Accident and Prognosis of Stochastic Effects," Devyat' let Chernobylyu. Meditsinskie posledstviya: Proceedings. Rel.2. Minsk, 1995, pp. 61-69 (in Russian).

10. Kenigsberg Ya. Eh., Minenko V.F., MoshCHIK K.V., "Radiological Situation in Belarus after the Chernobyl APS Accident, Biomedical Consequences and Scientific Justification of Activities on Radiation Protection of Population," Minsk, 1991, p. 30 (in Russian).

11. Knatko V.A., Sivako I.V., "Calculation of Dynamics of Exposure Dose of Cs-134 and Cs-137 Gamma-Radiation with Migration in Soil," Vestsi ANB. Seryya fizika-matehmatychnykh navuk. 1995, No. 2, pp. 93-96 (in Russian).

12. Kuznetsov V.A., Kol'nenKov V.P., Shagalova Eh. D. et al., "Plutonium-238, 239, 240 in River Deposits on the Territory of the North-East Trace of the Chernobyl Radioactive Pollution," Doklady ANB. 1993, Vol. 37, No. 6, pp. 104-107 (in Russian).

13. Lazyuk G.I., Nikolaev D.L., Ilina E.G., "Monitoring of Congenital Malformation in New-Born Children of Southern Areas of Gomel and Mogilev Regions," Zdravookhranenie Belarusi. 1990, No. 6, pp. 55-57 (in Russian).

14. Mazur V.A., Ustinovich A.K., Zubovich V.K. et al., "Health State of Pregnant, Bearing Women and New-Born Children in BSSR Regions Exposed to Radioactive Pollution in 1981-1989," Vestnik Akademii Meditsinskikh Nauk SSSR. 1991, No. 11, pp. 22-24 (in Russian).

15. Minenko V.F., Ukanovskij A.V., "Radiometric Control of Irradiation of BSSR Population," Zdravookhranenie Belarusi. 1990, 
No. 6, pp. 60-61 (in Russian).

16. Mironov V.P., DrugachenoK M.A., KUDRYASHOV V.P., "Dynamics of Radioactive Pollution of the Atmosphere of BSSR Towns," Vestsi AN BSSR. Seryya fizika-ehnergetychnykh navuk. 1991, No. 4, pp. 73-77 (in Russian).

17. Okeanov A.E., Antipova S.I., Karpovich V.A. et al., "Analysis of Morbidity of Population Affected by the Chernobyl APS Catastrophe in 1993," Minsk, 1994 (in Russian).

18. Petryaev E.P., Lejnova S.L., Sokolik G. A. et al., "Composition and Properties of Radioactive Particles Discovered in the Southern Areas of Belarus," Geokhimiya. 1993, No. 7, pp. 930-939 (in Russian).

19. Ustinovich A.K., Zubovich V.K., DombrovskiJ V. Yu. et al., "Cesium-137, Strontium-90 and Microelements Content in Mother's Milk from Radiocontaminated Areas of Belarus," Zdravookhranenie Belarusi. 1994, No. 12, pp. 30-33 (in Russian).

20. Khotyleva L.V., Dylenok L.A., YATSEVICH A.P. et al., "Effect of Increased Radiation Background on Chromosomal Aberration Frequency in Norway Spruce (Picea Abies (L) Karst.)," Doklady ANB. 1992, Vol. 36, No. 9-10. p. 842 (in Russian).

ACKNOWLEDGELMENT: This study was supported by the research grant of the Toyota Foundation. The authors would like to thank Dr. FoMICHENKo K.V. of the Institute of Radiobiology, Academy of Sciences of Belarus and other colleagues in Belarus for their collaroration during the study. The authors are also grateful to Ms. Cynthia HefFelfinger for her help in preparing the manuscript. 